\title{
Incidence and pattern of cerebrovascular diseases in Benghazi, Libya
}

\author{
PP ASHOK, K RADHAKRISHNAN, R SRIDHARAN, MA EL-MANGOUSH \\ From the Departments of Neurology and Medicine, University of Garyounis, Benghazi, Libya
}

SUMMARY During a 12 month study period, a total of 329 incident cases of stroke occurred in Benghazi, Libya. This provided an unadjusted annual incidence rate for stroke of 63 per 100,000 population; the corresponding rates for the male and female were 69 and 58 per 100,000 respectively. The sex dependent difference in the incidence was not statistically significant. Cerebral infarction was the commonest type of stroke accounting for $80.9 \%$. The incidence rates increased with age in all categories of stroke. Hypertension and ischaemic heart disease were common risk factors among the male patients, while diabetes and hypercholesterolaemia were more frequent in the female patients.

The incidence of cerebrovascular disease or stroke is reported to be declining. ${ }^{1}$ It is unclear whether this trend is a real decrease due to change in the prevalence of risk factors, or only an apparent decrease reflecting changes in the diagnostic fashion over time. The relative contribution of the racial characteristics and environmental factors towards susceptibility for this disease is still unsettled. Most of the population-based epidemiological studies on stroke from the developed countries of the world, ${ }^{2-9}$ show very high incidence of stroke. Studies representing the Jews in Israel, ${ }^{10}$ and the African Negro ${ }^{11}$ showed much lower incidence rates.

The people of Libya are of mixed Arab, African, Turkish and South European descent. ${ }^{12}$ It is not the purpose of this paper to discuss any new facts concerning the risk factors or type of stroke in Benghazi, but to report the incidence of cerebrovascular disease in this complex ethnic group situated in the north of Africa.

\section{Material and methods}

Situated in the north-eastern part of Libya on the southern Mediterranean coast, at a latitude of $32^{\circ} \mathrm{N}$ and a longitude of $20^{\circ} \mathrm{E}$, the city of Benghazi covers an area of $17,000 \mathrm{~km}^{2}$. The average mean temperature is $20^{\circ} \mathrm{C}\left(13^{\circ} \mathrm{C}\right.$ in January and $25^{\circ} \mathrm{C}$ in August) and annual precipitation rate is $26.5 \mathrm{~cm} .^{12}$

Address for reprint requests: Dr PP Ashok, PO Box 13426, Benghazi, Libya.

Received 14 June 1985 and in revised form 24 August 1985. Accepted 1 September 1985.
Medical organisation in Benghazi is efficient and comprehensive. Patients are referred from the walk-in polyclinics to the four university hospitals and to a rehabilitation centre for the handicapped. Private medical practice is not allowed. The people are affluent and medical care is free. In addition, state financed medical treatment abroad and desire to obtain disability certificates for tax benefits make people attend the clinics even for minor problems. Patients with neurological problems are referred from the medical clinics and university hospitals to the neurology outpatient clinics conducted in two of the polyclinics 5 days per week. The Neurology Unit in Seventh April Hospital, Benghazi, (the only one of its kind for the northeastern region of Libya), has three qualified neurologists. Neuroradiological investigations are facilitated by the availability of two computed tomography scanners in Benghazi. All the cases were personally examined by one of the neurologists.

Cranial CT was performed on 264 cases (80.2\%) within the first week of onset of stroke. The diagnosis and categorisation of the type of stroke was based on the algorithm laid down by the US National Survey of Stroke. ${ }^{13}$ All the cases were classified into (a) occlusive due to thrombosis or embolism (b) haemorrhagic, of intracerebral or subarachnoid type. Thus all the cases were categorised as "definite" or "highly probable" and avoided any case of stroke of "undetermined type".

A prospective search for all the incident cases of stroke occurring among the Libyan residents of Benghazi was made for a 12 month period between November 1, 1983 and October 31, 1984 through polyclinics, University hospitals and centres for the handicapped. Patients with only transient ischaemic attacks, previous history of stroke or those living outside the study area, were excluded from the study. The July, 1984 Libyan nationwide official census provided the population data.

The associated risk factors analysed in this study include hypertension (sustained systolic blood pressure 519 


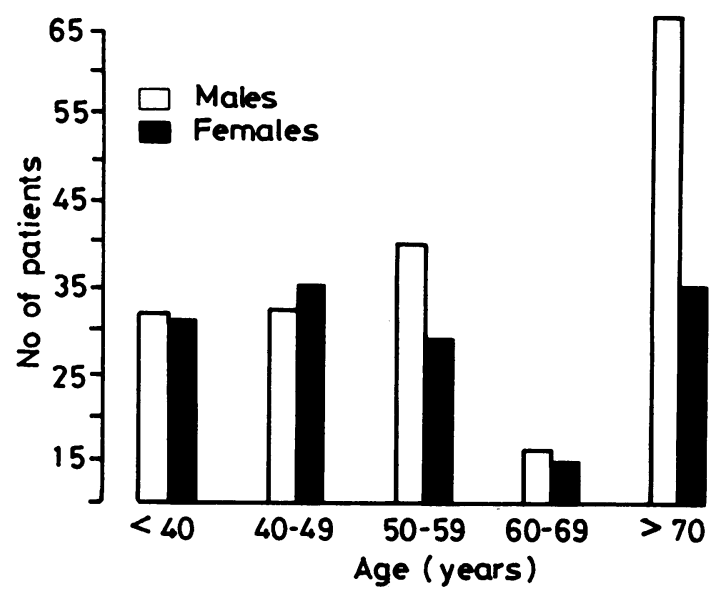

Fig 1 Age and sex distribution of the patients.

$>160 \mathrm{mmHg}$ and $/$ or a diastolic blood pressure $>95 \mathrm{mmHg}$ for at least one week after the stroke), diabetes mellitus (a casual blood glucose level $>160 \mathrm{mg} / \mathrm{dl}$ or a blood glucose level $>200 \mathrm{mg} / \mathrm{dl} 1$ hour after a $50 \mathrm{~g}$ oral glucose lead). hypercholesterolaemia (serum cholesterol $>260 \mathrm{mg} / \mathrm{dl}$ ) and ischaemic heart disease confirmed by a standard 12 lead ECG examination. In those patients who died within the first one week of stroke, a previous diagnosis of hypertension and diabetes or drug therapy for the same, were considered as evidence of these risk factors.

\section{Results}

The 329 incident cases of stroke consisting of 184 men and 145 women occurred in a population of 518,745 to give a crude annual incidence rate of 63 per 100,000 population per year. The crude incidence rate for men is 69 per 100,000 and for women is 58 per 100,000 population. The distribution of the patients by age and sex is shown in fig 1 . The sex difference between the number $\left(\chi^{2}=6.907, \mathrm{p}<0.5,>0.1\right)$ was not significant.

The age and sex specific incidence rates for total strokes are given in table 1 . In both the sexes, the rates gradually increased with the age, and were highest above 70 years of age. Excepting for the 4th decade,

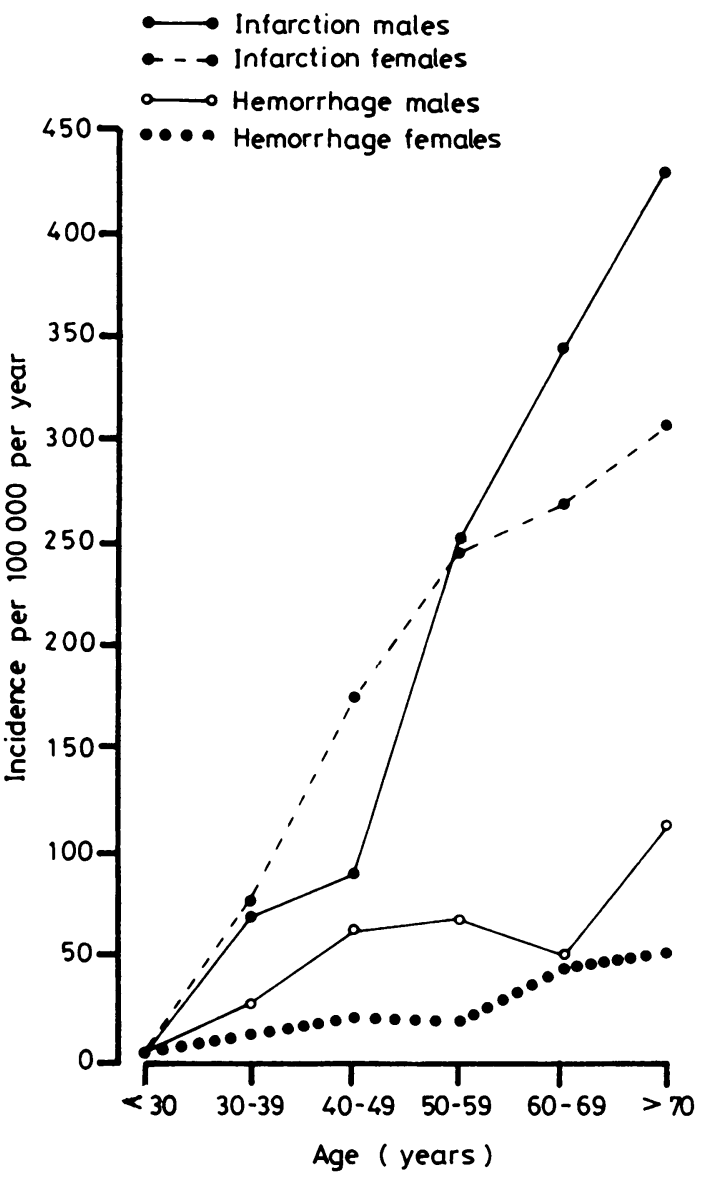

Fig 2 Incidence of stroke, by diagnostic category, age and sex.

the crude incidence rates for males were higher than the females. The Libyan population in Benghazi above 15 years of age is 251,511 giving an incidence rate of $131 \cdot 1$ per 100,000 population above 15 years of age. Similarly the total incidence rate in the age group 15-65 years was 92.9 per 100,000 population.

Cerebral infarction constituted $80.9 \%$ (thrombosis

Table 1 Age-and sex-specific incidence rates of stroke (per 100,000 population per year) in Benghazi.

\begin{tabular}{|c|c|c|c|c|c|c|c|c|}
\hline \multirow{2}{*}{$\begin{array}{l}\text { Age } \\
\text { (yr.) }\end{array}$} & \multicolumn{3}{|l|}{ Male } & \multicolumn{3}{|l|}{ Female } & \multicolumn{2}{|l|}{ Both sexes } \\
\hline & Population & No. of cases & Rate & Population & No. of cases & Rate & No. of cases & Rate \\
\hline $\begin{array}{l}<30 \\
30-39 \\
40-49 \\
50-59 \\
60-69 \\
>70 \\
\text { All ages }\end{array}$ & $\begin{array}{r}192,289 \\
25,851 \\
21,123 \\
12,290 \\
4,100 \\
11,937 \\
267,590\end{array}$ & $\begin{array}{r}6 \\
26 \\
32 \\
39 \\
16 \\
65 \\
184\end{array}$ & $\begin{array}{r}3 \\
101 \\
152 \\
317 \\
390 \\
545 \\
69\end{array}$ & $\begin{array}{r}182,740 \\
24,652 \\
18,425 \\
10,650 \\
4,515 \\
10,173 \\
251,155\end{array}$ & $\begin{array}{r}9 \\
22 \\
36 \\
28 \\
14 \\
36 \\
145\end{array}$ & $\begin{array}{r}5 \\
89 \\
195 \\
263 \\
310 \\
354 \\
58\end{array}$ & $\begin{array}{r}15 \\
48 \\
68 \\
67 \\
30 \\
101 \\
329\end{array}$ & $\begin{array}{r}4 \\
96 \\
172 \\
292 \\
348 \\
457 \\
63\end{array}$ \\
\hline
\end{tabular}


Table 2 Incidence rates of stroke by age, sex, and diagnostic category

\begin{tabular}{|c|c|c|c|c|c|c|c|c|}
\hline \multirow{3}{*}{$\begin{array}{l}\text { Age } \\
(y r .)\end{array}$} & \multicolumn{4}{|c|}{ Cerebral Infarction } & \multicolumn{4}{|c|}{ Haemorrhage } \\
\hline & \multicolumn{2}{|c|}{ Male } & \multicolumn{2}{|c|}{ Female } & \multicolumn{2}{|c|}{ Male } & \multicolumn{2}{|c|}{ Female } \\
\hline & No. & Rate & No. & Rate & No. & Rate & No. & Rate \\
\hline $\begin{array}{l}<30 \\
30-39 \\
40-49 \\
50-59 \\
60-69 \\
>70 \\
\text { Total }\end{array}$ & $\begin{array}{r}5 \\
18 \\
19 \\
31 \\
14 \\
52 \\
139\end{array}$ & $\begin{array}{r}3 \\
70 \\
90 \\
252 \\
342 \\
436 \\
52\end{array}$ & $\begin{array}{r}7 \\
19 \\
32 \\
26 \\
12 \\
31 \\
127\end{array}$ & $\begin{array}{r}4 \\
77 \\
174 \\
244 \\
266 \\
305 \\
51\end{array}$ & $\begin{array}{r}1 \\
8 \\
13 \\
8 \\
2 \\
13 \\
45\end{array}$ & $\begin{array}{r}1 \\
31 \\
62 \\
65 \\
49 \\
109 \\
17\end{array}$ & $\begin{array}{r}2 \\
3 \\
4 \\
2 \\
2 \\
5 \\
18\end{array}$ & $\begin{array}{r}1 \\
12 \\
22 \\
19 \\
44 \\
49 \\
7\end{array}$ \\
\hline
\end{tabular}

$69 \cdot 6 \%$, embolism $11 \cdot 3 \%$ ) of the total strokes, while haemorrhagic stroke contributed to the remaining $19 \cdot 1 \%$ (intra cerebral $14 \cdot 6 \%$, subarachnoid $4 \cdot 5 \%$ ). The incidence of haemorrhagic stroke was considerably higher in the males for all the age groups. On the other hand incidence of cerebral infarction was higher among the females up to the fifth decade, after which the males predominate (fig 2, table 2). Fifty seven incident cases died during the first month of the onset of stroke (case fatality ratio $17 \cdot 3 \%$ ). This comprised 35 cases of occlusive stroke and 22 cases of cerebral haemorrhage; the corresponding case fatality ratios were $13 \%$ and $35 \%$ respectively (table 3 ).

Among the 266 patients of stroke occurring after the age of 40 years, eighteen patients did not have any associated risk factor. Hypertension was the commonest association accounting for $54 \%$ of the cases, and were more common in the males. While hypercholesterolaemia and diabetes were more frequent among the females, ischaemic heart disease was commoner among the males (fig 3).

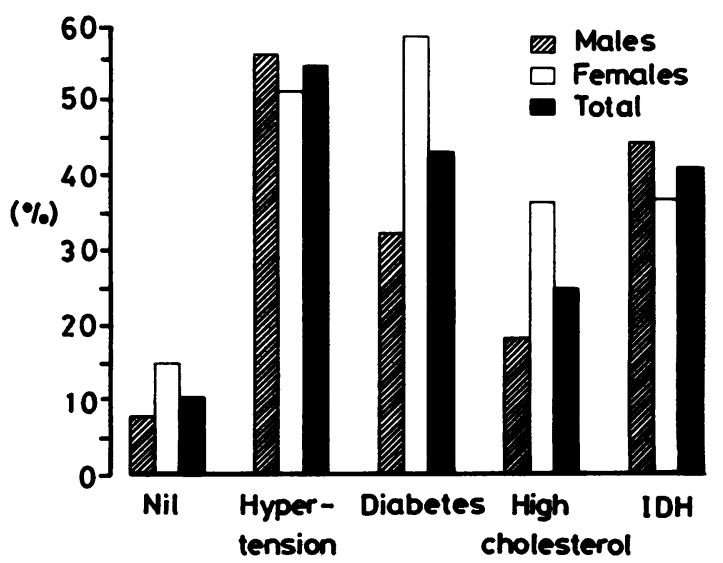

Fig 3 Percentage distribution of risk factors for all types of strokes.
Table 3 Case fatality ratio by age, sex and diagnostic category

\begin{tabular}{|c|c|c|c|c|c|}
\hline \multirow{3}{*}{$\begin{array}{l}\text { Age } \\
\text { group } \\
\text { (yr.) }\end{array}$} & \multicolumn{5}{|c|}{ Case fatality ratio (\%) } \\
\hline & \multicolumn{2}{|c|}{ Infarction } & \multicolumn{2}{|c|}{ Haemorrhage } & \multirow[t]{2}{*}{ Total } \\
\hline & Male & Female & Male & Female & \\
\hline $\begin{array}{l}<40 \\
40-59 \\
>60 \\
\text { All ages }\end{array}$ & $\begin{array}{c}-\overline{8} \\
19 \cdot 7 \\
12 \cdot 2\end{array}$ & $\begin{array}{r}11 \cdot 5 \\
8 \cdot 6 \\
23 \cdot 3 \\
14 \cdot 2\end{array}$ & $\begin{array}{l}44 \cdot 4 \\
23 \cdot 8 \\
40 \\
33 \cdot 3\end{array}$ & $\begin{array}{l}20 \\
50 \\
42.9 \\
38.9\end{array}$ & $\begin{array}{l}12 \cdot 7 \\
12 \cdot 6 \\
24 \cdot 4 \\
17 \cdot 3\end{array}$ \\
\hline
\end{tabular}

Table 4 Incidence rate of stroke (per 100,000 per year) in various studies

\begin{tabular}{|c|c|c|c|c|}
\hline $\begin{array}{l}\text { Reference } \\
\text { No. }\end{array}$ & Place & Population & $\begin{array}{l}\text { No. of } \\
\text { cases }\end{array}$ & Rate \\
\hline \multirow{2}{*}{$\begin{array}{l}\text { Present } \\
\text { Study }\end{array}$} & \multirow{2}{*}{$\begin{array}{l}\text { Benghazi, } \\
\text { Libya } \\
\text { Oxfordshire, } \\
\text { England }\end{array}$} & 518,745 & 329 & 63 \\
\hline & & 660,391 & 168 & 163 \\
\hline 3 & $\begin{array}{l}\text { Kuopia, } \\
\text { Finland }\end{array}$ & 95,420 & 373 & 235 \\
\hline 4 & \multirow{3}{*}{$\begin{array}{l}\text { Middlesex, } \\
\text { Connecticut } \\
\text { Auckland, } \\
\text { New Zealand } \\
\text { Mannitoba, } \\
\text { Canada }\end{array}$} & 83,500 & 191 & 230 \\
\hline 5 & & 829,464 & $535^{*}$ & 130 \\
\hline 6 & & 660,391 & 1367 & 138 \\
\hline 7 & \multirow{2}{*}{$\begin{array}{l}\text { Rochester, } \\
\text { Minnesota } \\
\text { Jerusalem, } \\
\text { Israel }\end{array}$} & 42,809 & 993 & 154 \\
\hline 10 & & 208,750 & 1522 & 90 \\
\hline 11 & $\begin{array}{l}\text { Ibadan, } \\
\text { Nigeria }\end{array}$ & 611,539 & 318 & 26 \\
\hline
\end{tabular}

*50\% patients sampled.

\section{Discussion}

The crude annual incidence rate for stroke in Benghazi of 63 per 100,000 population, appears lower than the corresponding rates from most of the developed countries of the world. ${ }^{2-9}$ Knowledge of the population at risk, diagnostic precision, and the availability of a comprehensive and free medical care facility in 
Benghazi, ensure the reliability and completeness of the present epidemiological study.

Most of the reported incidence rates for stroke from Europe and North America show a wide fluctuation ranging between 130 and 830 per 100,000 population. ${ }^{2-9}$ (table 4). There are however scanty population-based epidemiological data available from the developing countries. The incidence of $26 \mathrm{per}$ 100,000 population in the Nigerian African ${ }^{11}$ is far below the Benghazi figure. It is unclear whether this difference is attributable to genetic or environmental factors. It has been reported that the US blacks experience a higher stroke rate than the whites. ${ }^{8}$ On the contrary, the incidence was three times as high among the Japanese in Japan as compared with Japanese-Americans in Hawaii, ${ }^{14}$ suggesting an environmental factor.

The population of Benghazi is relatively young as compared with those of the developed countries of Europe and North America. Since strokes, especially cerebral infarction are common at the age 65 - or over in both sexes, ${ }^{15}$ difference in total incidence rates may reflect dissimilarities in the age structure of the population. The difference can be avoided when the agespecific rates are determined. It is of interest to note that while $77 \%$ of strokes in the Middlesex study ${ }^{4}$ occurred above 65 years of age, the corresponding figure for Benghazi is only $35 \%$. The incidence of 92.9 per 100,000 in the 15-65 year age group for Benghazi is much higher than the corresponding rates of 54.7 and 73 for Auckland ${ }^{5}$ and Göteborg ${ }^{16}$ respectively. This is however in contrast with the above 15 years age incidence rate of $131 \cdot 1$ per 100,000 for Benghazi being lower than the corresponding figure of 174 for Auckland. ${ }^{5}$ Also the total estimated incidence of 200 per 100,000 for Göteborg ${ }^{16}$ is far higher than that of the present study. It becomes very clear that the incidence of stroke in Benghazi is not low as reflected by the unadjusted rates.

Cerebral infarction $(80.9 \%)$ was the most frequent and subarachnoid haemorrhage (4.5\%) the least common in the present study, concordant with most other reports. The Framingham study ${ }^{17}$ reported $18 \%$ incidence of subarachnoid haemorrhage; this high incidence was postulated as a reflection of the younger age of the population. The Benghazi population also being relatively young, the high incidence of cerebral infarction and very low incidence of subarachnoid haemorrhage is unexpected.

The total case fatality ratio of $17 \cdot 3 \%$ for all strokes in Benghazi is far below that of the Nigerian African. ${ }^{11}$ Mortality rates for cerebrovascular disease have been declining in most countries since 1920, with the decrease continuing to the present time. Concordant with most other reports, haemorrhagic stroke caused a higher mortality than did infarctions.
Excepting for the young male strokes, the mortality rates were higher among the female patients in all other ages irrespective of the type of stroke.

Hypertension is accepted as the commonest risk factor for stroke $\mathrm{e}^{1920}$ and was the single most common association accounting for $54 \%$ of cases in Benghazi. The role of hypercholesterolaemia is controversial, ${ }^{15}$ although along with diabetes it was far more common among the female Libyan subjects.

The authors express their gratitude to $\mathrm{Dr} M$ Narayanappa, Department of Family and Community Medicine for his help in the population data analysis and to Miss Gwen Vestidas for secretarial assistance and typing the manuscript.

\section{References}

${ }^{1}$ Garraway WM, Whisnant JP, Furlan AJ, Philips LH, Kurland LT, O'Fallon WM. The declining incidence of stroke. N Engl J Med 1979;9:449-51.

${ }^{2}$ Oxfordshire Community Stroke Project. Incidence of stroke in Oxfordshire: first year's experience of a community stroke register. $\mathrm{Br} \mathrm{Med} \mathrm{J} \mathrm{1983;287:713-7.}$

${ }^{3}$ Sivenius J, Rickkinen P, Pyorala K, Heinonen OP. Epidemiology of Stroke in Kuopio area, Finland. Acta Neurol Scand (suppl 90) 1982;65:173.

${ }^{4}$ Eisenberg H, Morrison J, Sullivan P, Foote FM, Hartford C. Cerebrovascular accidents: incidence and survival rates in a defined population, Middlesex County, Connecticut. JAMA 1964;189:883-8.

${ }^{5}$ Bonita R, Beaglehole R, North JDK. Event, incidence and case fatality rates of cerebrovascular disease in Auckland, New Zealand. Am J Epidemiol 1984;120:236-43.

${ }^{6}$ Abu Zeid HAH, Choi NW, Nelson NA. Epidemiologic features of cerebrovascular disease in Manitoba: incidence by age, sex and residence, with etiologic implications. Can Med J 1975;113:379-84.

${ }^{7}$ Matsumoto N, Whisnant J, Kurland LT, Okazaki N. Natural history of stroke in Rochester, Minnesota, 1955 through 1969: an extension of a previous study, 1945 through 1954. Stroke 1973;4:20-9.

${ }^{8}$ Siekert RG. Cerebrovascular Disease Survey Report for the Joint Council Subcommittee on Cerebrovascular Disease. NINLDS and NHLI. Rochester, Whiting Press, 1976.

${ }^{9}$ Worth RM, Kato M, Rhoads, GC, Kagan A, Syne SL. Epidemiologic study of coronary heart disease and stroke in Japanese men living in Japan, Hawaii and California: mortality. Am J Epidemiol 1975;102:481-90.

${ }^{10}$ Melamed E, Cahane E, Carmon A, et al. Stroke in Jerusalem district 1960 through 1967: an epidemiologic study. Stroke 1973;4:465.

${ }^{11}$ Osuntokun BO, Bademosi O, Akinkugbe OO, Oyediran ABO, Carlisle R. Incidence of stroke in an African city: results from the Stroke Registry at Ibadan, Nigeria, 1973-1975. Stroke 1979;10:205-7.

${ }^{12}$ Hajjaji SA. The New Libya. A Geographical, Social, Economic and Political Study. Tripoli, Muassasat Assaria. 1972:205-9. 
${ }^{13}$ Weinfield FD. National survey of stroke. Stroke 1981;12:1-55.

${ }^{14}$ Takeya Y, Popper JS, Shimizu Y, Kato H, Rhoads GG, Kagan A. Epidemiologic studies of coronary heart disease and stroke in Japanese men living in Japan, Hawaii and California: incidence of stroke in Japan and Hawaii. Stroke 1984;15:15-23.

${ }^{15}$ Lin $\mathrm{CH}$, Shimizu Y, Kato H, et al. Cerebrovascular diseases in a fixed population of Hiroshima and Nagasaki, with special reference to relationship between type and risk factors. Stroke 1984;15:653-60.

${ }^{16}$ Harmsen P, Berglund G, Larsson O, Tibblin G, Wilhelmsen L. Stroke registration in Göteborg, Sweden, 1970-75. Acta Med Scand 1979;206:337-44.

${ }^{17}$ Kannel WB, Dawber TR, Cohen ME, McNamara PM.
Vascular disease of the brain-epidemiologic aspects. The Framingham study. Am J Public Health 1965; 55:1355-66.

${ }^{18}$ Kramer S, Diamond El, Lilienfeld AM. Patterns of incidence and trends in diagnostic classification of cerebrovascular disease in Washington County, Maryland, 1969-1971 to 1974-1976. Am J Epidemiol 1982;115: 398-411.

${ }^{19}$ Kannel WB, Philip AW, Verter J, McNamara PM. Epidemiologic assessment of the role of blood pressure in stroke. The Framingham Study. JAMA 1970;214: 301-10.

${ }^{20}$ Shekelle RB, Ostfeld AM, Kalavans HL. Hypertension and risk of stroke in elderly population. Stroke 1974; 5:71-5. 